\author{
(online) $=$ ISSN $2285-3642$ \\ ISSN-L = $2285-3642$ \\ Journal of Economic Development, Environment and People \\ Volume 10, Issue 3, 2021 \\ URL: http://jedep.spiruharet.ro \\ e-mail: office jedep@spiruharet.ro
}

\title{
Mediating Effect of Organization Learning on the Relationship Between Strategic Change, Knowledge Management and Transformational Leadership ; Case of Indonesia Islamic Banks
}

\author{
Muhammad Richo Rianto ${ }^{1}$, Farida Jasfar ${ }^{2}$ and Willy Arafah ${ }^{3}$ \\ ${ }^{1}$ Faculty of Economics and Business, Bhayangkara Jakarta Raya University, Jakarta, Indonesia \\ ${ }^{2,3}$ Faculty of Economics and Business Trisakti University, Jakarta, Indonesia
}

\begin{abstract}
This study aims to know influence the mediation of organization learning on strategic change, knowledge management and transformational leadership and performance of Indonesian Islamic Banks. Design / methodology / approach - This study uses quantitative research with a purposive sampling technique with a population of 14 Indonesian islamic banks. The targeted unit of analysis is the Islamic banks manager. There were 239 questionnaires returned and 11 of them did not meet the requirements, so only 228 were used in this study. This study uses SmartPLS 3 to test the hypothesis. This research shows that strategic change, knowledge management and transformational leadership affect organization learning. This study also shows that strategic change, transformational leadership knowledge management and organization learning have an effect on firm performance. Apart from that, the mediating role of the learning organizations also provides consistent results. Research limitation / implications - Islamic banks managers must be able to identify the importance of change for the company, because of the big risks. Supporting knowledge and leadership skills in companies makes Islamic banking better competitive. These three variables become better if the company uses a learning organization because the company will change more quickly and achieve better performance with previous experience.
\end{abstract}

Originality / value - Similar research is usually carried out in manufacturing and service companies and is carried out in developed countries (Europe, America and Africa). The focus of this research is the development of strategic change supported by knowledge management and transformational leadership on performance mediated by learning organizations. This research was also conducted for the first time in Asia with the object of Islamic banks in Jakarta - Indonesia.

Keywords: Strategic change, Knowledge management, Transformational leadership, Organization learning, Firm performance, Islamic Banks, Jakarta - Indonesia

JEL Codes: G10, G21

How to cite: Rianto, M., Jasfar, F., \& Arafah, W. (2021). Mediating Effect of Organization Learning on the Relationship Between Strategic Change, Knowledge Management and Transformasional Leadership : Case of Indonesian Islamic Banks. Journal of Economic Development, Environment and People, 10(3), 26-49. doi:http://dx.doi.org/10.26458/jedep.v10i3.697

\section{Introduction}

Adapting to rapid technological developments and a dynamic environment means that financial services must be able to determine strategic changes in response to market demand, technological novelty 


\author{
(online) $=$ ISSN $2285-3642$ \\ ISSN-L = $2285-3642$ \\ Journal of Economic Development, Environment and People \\ Volume 10, Issue 3, 2021 \\ URL: $\underline{\text { http://jedep.spiruharet.ro }}$ \\ e-mail: office jedep@spiruharet.ro
}

and competition [1]. Technological advances have made competition in the financial services industry tougher after the entry of many technology financial companies [2].

Sharia banks is one of the competitors in the financial services industry which is currently being calculated. The growth of the Islamic industry today has made the pattern of Islamic finance attractive. The majority of the population of $87.17 \%$ are Muslim in Indonesia make islamic banks have better performance in the future. The 2021 Sharia Banks Statistics (SBS) notes that the Islamic banks industry is growing and developing rapidly, where in 2007 Indonesia only had 3 Islamic banks and until 2019 Indonesia had 14 Islamic Commercial Banks (BUS), 20 Sharia Business Units (UUS) and 165 Sharia Rural Banks (BPRS).

Based on the 2019 [3] in the last three years 2017 - 2019 the growth of Islamic banking has undergone significant changes. Islamic banking has experienced a positive performance trend over the past 3 years with an increase in total assets of 47 trillion rupiah in the 2017-2018 period and 9 trillion rupiah in 20182019. Likewise, the lending sector in Islamic banks increased by 36 trillion rupiah in the 2017-2018 period and 14 trillion rupiah in the 2018-2019 period. The same thing also happened to the third party funds (DPK) sector, which grew significantly from year to year. The significant growth of Islamic bank is also supported by a strategic Islamic banks network, especially in DKI Jakarta.

Jakarta is the epicenter of economic growth in Indonesia. A multicultural population with high diversity makes Jakarta the center of Indonesia's economy. As the center of Indonesia's economy, many investors and companies make Jakarta a strategic target market. Sharia banking is one of the many businesses that have made Jakarta a target market with 252 branches spread across the DKI Jakarta area under West Java which has a larger area. Jakarta as the epicenter of Indonesia economy makes islamic banks have to compete fiercely. Conventional banks and financial technology (FinTech) companies are competitors who are currently strong rivals in the industrial era 4.0. However, amidst intense competition, the development of Islamic banks produced very satisfying results with an increase in market share from $5 \%$ to $6.1 \%$ in October 2019.

Strategy change becomes important because it is a means by which companies can survive from competitors and environmental changes which are a threat to company performance (Mohammad, 2019). Therefore the company must be able to learn to initiate strategic change that is in accordance with the environment in which the company operates to gain increased performance and competitive advantage over competitors ([4], [5]). Some of the literature that examines strategic change has been carried out by researchers so as to provide opportunities to find new developments [1], [6]-[10]. Several studies on changing marketing strategies have yielded inconsistent conclusions. Research[11]-[13] found that strategy changes have a positive effect on the survival of banking companies in Spain. However, in research [14] it was found that strategic changes had an effect on organizational performance and had a negative impact on the company's sustainability. 


\author{
(online) $=$ ISSN $2285-3642$ \\ ISSN-L = $2285-3642$ \\ Journal of Economic Development, Environment and People \\ Volume 10, Issue 3, 2021 \\ URL: http://jedep.spiruharet.ro \\ e-mail: office jedep@spiruharet.ro
}

The development of knowledge management was pioneered by thinkers such as Peter Drucker 1970, Karl-Erik Sveiby 1980, and Nonaka and Takeuchi 1990 [15]. Many researchers consider that knowledge management is something that is important in an organization. This is based on the fact that knowledge is the most potential resource and contributes to competitiveness for companies [15]. Developing and maintaining knowledge management is essential for the survival and long-term success of a company [16]. Some literatures get inconsistent results of the influence of knowledge management in improving performance. Research [17]-[21] produce that knowledge management affects company performance, but different results are shown by research that conducted by [22], [23] which resulted that there was no influence of knowledge management on company performance.

The business dynamics that are always changing all the time make the company still look for factors that can improve the company's performance in order to survive the competition [24]. Leadership is an important part of the business process because the company's success is determined by the leader. A good leadership style tends to have a positive impact on the organization. Much of the literature discusses the influence of leadership on organizational performance. Leadership in many literatures is researched in two dimensions, namely transactional leadership and transformational leadership. Leadership in this study focuses on transformational leadership.

Transformational leadership is a part of leadership which has become a critical success factor in many companies today. The rapidly changing business environment makes a leader must be able to motivate and inspire his subordinates. Some literature explains that having a leader who has transformational leadership can affect the company's performance better than before [24]-[26].

Company performance is an important issue for any organization that wants to survive and survive. Many studies have made transformational leadership a factor that affects company performance. However, several studies on the effect of transformational leadership on company performance are still being debated. Research [25] which examines the effect of transformational leadership on company performance results in that transformational leadership affects organizational performance. However, it is different from research [24] conducted at universities in Surabaya which examined the effect of transformational leadership on company performance which resulted in transformational leadership not having an effect on company performance.

Learning organizations are an effective and efficient approach to responding to business challenges and allow companies to adapt flexibly in fast business growth [10]. The company's strategy has an influence on company performance which is mediated by the learning organization. This happens because with learning organizations, companies can maintain a competitive advantage in a dynamic environment and have an impact on improving company performance[8], [10], [27]. 


\author{
(online) $=$ ISSN $2285-3642$ \\ ISSN-L = $2285-3642$ \\ Journal of Economic Development, Environment and People \\ Volume 10, Issue 3, 2021 \\ URL: http://jedep.spiruharet.ro \\ e-mail: office jedep@spiruharet.ro
}

Some literature shows that learning organizations have a mediating role in the effect of changing marketing strategies on company performance [10], this is the case with the mediating role of learning organizations from the influence of knowledge management on company performance in research [28]. The same thing also resulted in the mediating role of the effect of transformational leadership on company performance [24].

This research is different from other studies. This research focuses on changing the marketing strategy whose concept was developed by[8], [29] and was first applied by [10] to banking in Nigeria. This research continues research [10] which adds to the importance of knowledge management and transformational leadership as well as the mediation role of learning organizations in it. This research is also different from many similar studies because the object of research is carried out in Islamic banks located in DKI Jakarta, which is the epicenter of the Indonesian economy and with a country with a majority Muslim population.

\title{
2. Literature Review
}

\subsection{Marketing Strategic Change (MSC)}

Change in strategy is an important phenomenon because it is a way for many companies to survive in a competitive, political, economic, social, technological and legal environment that is constantly changing and threatening the survival and effectiveness of the company [9]. Strategic change is part of the Resource base theory (RBT) [7]. Strategic change has attracted the attention of researchers in strategic management science. The beginning of research that developed the concept of strategic change was [7], [8]. Resource Base Theory is the theory most widely used in strategic management and the main focus of resource base theory is on managing resources and the company's internal capabilities [9]. Resource base theory explains that in strategic management, the most fundamental resources and have a competitive advantage are valuable internal resources that cannot be replicated [30].

The theory resource base view (RBV) partly based on understanding how companies can use individual capabilities as a source of competitive advantage. Theories source of competitive advantage according to the theory of resource base view (RBV) that companies should have competitive advantages that precious(valuable), rare(rare), imitate and no substitutions(non-substitutable) [30]-[35]. It is stated by Barney (1991) that most of the research on sources of sustainable competitive advantage has focused both on isolating firm opportunities and threats (Porter, 1980,1985), describing its strengths and weaknesses Hofer and Schendel, 1978; Penrose, 1958; Stinchcombe, 1965, or analyze how these are synchronized to select strategies.

Different views in strategic change research are an important part of positioning the company. The first view focuses on how companies change poor performance through changing strategies [6], [11]. They view that the decline in company performance is caused by a wrong strategy so that changes must be made. The 


\author{
(online) $=$ ISSN $2285-3642$ \\ ISSN-L = $2285-3642$ \\ Journal of Economic Development, Environment and People \\ Volume 10, Issue 3, 2021 \\ URL: http://jedep.spiruharet.ro \\ e-mail: office jedep@spiruharet.ro
}

second view focuses that the company can survive and improve performance by continuing to make strategic changes that focus on aligning strategies according to market needs [36]. Both of these views have in common that the change strategy is used to improve company performance, but what distinguishes it is the timing of strategy change implementation, where the first view applies to changing performance. companies that have decreased while the second view makes changes to strategies to survive.

Islam views change as something that is important to do [37]. (Surah al-Ra'ad / 13: 11) explains the importance of change. Strategic change can be defined as a change in shape, quality or state from time to time [38] within an organization. Strategic change is the most dynamic field in strategic management science [10]. Strategy change is also known as one of the main sources in improving company performance [4], [6], [7].

Strategic change is the main way companies maintain their conditions. shifting competitive, demand, technology, and the social environment [1]. Strategic change is a very important part of the science of strategic management[9] and is the key to a company's success in improving company performance[6][8][1], [9], [10]. The concept of strategic change in this study is adopted from research [4] where the focus of strategic change is on the development of MSC (Marketing Strategic Change) which is different from innovation in marketing where the emphasis is only on "innovation". Some literature that describes innovation is defined as the tendency and capacity to introduce new products [39]. However, the change in marketing strategy is not only focused on introducing new products, but changes in the breadth of product and service offerings that include not only existence but elimination [4].

\title{
2.2. Knowledge Management (KM)
}

Knowledge management theory comes from the knowledge base view, which is a new view of-based resources intellectual capital. The knowledge base view comes from the resource base view which shows that knowledge in various forms is a resource for the company [40]. The terminology of the knowledge base view which began to be built from the growth theory of the firm Penrose, 1959 was then further developed by [32] where knowledge management is the main foundation and is then continued by [30] with resources. base view where resources are said to be strategic if they meet several criteria, namely rare, valuable, difficult to imitate and difficult to replace which then raises new thoughts about knowledge base view by [41]. The knowledge base view views that human capital enables companies to adapt to various problems to achieve better performance.

The view of knowledge as a strategic resource is based on the viewpoint of the theory Resource base view (RBV), starting from the work of Penrose (1959), Barney (1991), Grant (1996), Peteraf (1993) and Wernerfelt (1984). Knowledge management is a set of procedures designed to manage productive knowledge enhancement and enhancement of learning, sharing and decision making in organizations. Knowledge management is a multidimensional construction which is a collection of sources of knowledge, 


\author{
(online) $=$ ISSN $2285-3642$ \\ ISSN-L = $2285-3642$ \\ Journal of Economic Development, Environment and People \\ Volume 10, Issue 3, 2021 \\ URL: http://jedep.spiruharet.ro \\ e-mail: office jedep@spiruharet.ro
}

conversion of knowledge, dissemination of knowledge, application of knowledge and reuse of knowledge [15].

The organization that creates knowledge is an organization that connects tacit knowledge and explicit knowledge. According to Nonaka and Takeuchi (1995) there are two types of knowledge, namely tacit knowledge and explicit knowledge. Tacit knowledge is very difficult to communicate, define and share with others. Tacit knowledge is an understanding of one's own thoughts and experiences. Tacit knowledge arises from actions, procedures, routines, commitment, ideals, values and emotions[42], [43].

The Islamic view of knowledge predicts the importance of knowledge. There are many verses in the AlQuran that explain the importance of knowledge for a person. This is evidenced by the verses that were first revealed by Allah SWT through the angel Jibril to Prophet Muhammad SAW in the context of knowledge contained in QS Al-Alaq (96): 1- 5. In addition, Allah SWT in QS Al Mujadalah (58): 1 states that people who have knowledge will be elevated by Allah SWT. Surah Al-Zumar (39): 9 also strengthens the importance of knowledge in Islam where Allah SWT implies that there is a difference between a knowledgeable person and someone who is not knowledgeable.

Based on the arguments and conclusions from the various sources above, it can be concluded that knowledge management is an important part of human life. Human ability in managing knowledge becomes a competitive resource for the company, so that the company has value to be able to compete with competitors. Good knowledge management will be difficult to imitate by competitors so that it becomes a competitive advantage for the company which has an impact on improving company performance.

\title{
2.3. Transformational Leadership
}

Penrose (1959) initiated the theory of corporate growth in (the growth theory of the firm) this theory states that the company is a collection of productive resources. The resources in question are human resources and non-human resources. This theory then becomes a basic reference for the development of resource-based theory (resource base view) put forward by [30]. The theory was resource base view later derived [41] to become Knowledge Base View (KBV). Weber started thinking about leadership in 1947, which later developed into charismatic leadership and further grew in to behaviorally leadership. The development of thinking about leadership styles at that time was transformational leadership. According to [44]) the transformation leadership was first by Downton in 1973. Leadership theory began with a classic work by political sociologist James Macgregor Burn in 1978 [45] with the title of his book "Leadership" which explains the influence between leaders with followers to achieve leadership goals and are specifically developed by [46].

Transformational leadership is a type of leader who motivates subordinates through inspiration [46]. The development of transformational leadership still continues today. Leaders in organizations take an important part in achieving organizational goals. A leader in his leadership needs a leadership style that 


\author{
(online) $=$ ISSN $2285-3642$ \\ ISSN-L = $2285-3642$ \\ Journal of Economic Development, Environment and People \\ Volume 10, Issue 3, 2021 \\ URL: http://jedep.spiruharet.ro \\ e-mail: office jedep@spiruharet.ro
}

must be shown to his followers. Leadership is a leader's ability to influence employees in an organization [37].

Islam views leadership as a task (mandate), a test, a responsibility from a god whose responsibility is not only limited to humans but to Allah SWT [47] There are several terms that refer to the meaning of leader. This is said in the Al-Quran surah An-Nisa ': 59. In this surah An-Nisa said that "ulil amri" is a power holder (leader) who has the mandate to be able to take care of other people's affairs. In other words, a leader is a person who has the mandate to be able to guide, direct, motivate, become a role model to his subordinates (follower) to achieve organizational goals for the common good. The behavior of the leader of the most ideal in Islam to be an example(rolemodel)as has been exemplified by the prophets and apostles (Maulizar et al., 2012), as described in the Quran surah Al - Ahzab verse 21: "It'sinside apostle of Allah you can be the best example if you expect the mercy of Allah, and (salvation) at the end and always remember Allah". (Surah Al-Ahzab: 21).

\title{
2.4. Learning Organization (OL)
}

The main theory of learning organizations was introduced by [48] by issuing the book "Fifth Discipline" where learning organizations are organizations that continually learn and expand their capacity to create the results they really want, where opinions and learn. together to achieve common goals. [48] describes the five pillars in achieving a learning organization, namely a system of thinking, personal mastery, mental model, spreading vision, share vision, and team learning. With the same approach, this theory was developed by [49] which explains that the characteristics of knowledge created by companies are a place where finding new knowledge is not a special activity. In its development, the learning organization theory provides many views. According to [4] learning is consistent with discussions about issues and strategic momentum. A company with a high level of routine and experience for the company tends to minimize risk. When an organization faces high uncertainty, it tends to learn from past experiences that accumulate to form knowledge [50] Supported by a good learning organization where learning and practice have a major influence on decision making in improving company performance [50].

\subsection{Firm Performance}

Resource Base View (RBV) provides the view that increasing the business performance of an organization or company can occur by increasing stationary resources [15]. Companies with good performance must build a business by considering knowledge as an important resource in obtaining superior performance. Based on thetheory, the resource base view (RBV) knowledge possessed by a company or organization must be well recognized as a fundamental resource (basic) in gaining a competitive advantage [15].

Changes in the business environment mean that companies must be able to use knowledge appropriately where the company must be able to acquire knowledge, change knowledge and make products or services meaningful. The company can not improve its performance if the company is unable to manage knowledge (KnowledgeManagement) [15]. 


\author{
(online) = ISSN $2285-3642$ \\ ISSN-L = $2285-3642$ \\ Journal of Economic Development, Environment and People \\ Volume 10, Issue 3, 2021 \\ URL: http://jedep.spiruharet.ro \\ e-mail: office jedep@spiruharet.ro
}

\title{
2.6. Framework
}

Several researchers have found a positive and significant influence between changes in marketing strategy and company performance [10]. The same thing was also found in the existence of a positive and significant influence of knowledge management on company performance [17], [18]. Research on transformational leadership also has a positive and significant impact on company performance [25].

However, research ([14] provides a different view that changes in strategy on company performance as well as research which reports that knowledge management has no effect on company performance [23] and research [24] who reported that transformational leadership has no influence on company performance.

It is therefore necessary to consider the mediating variables to effectively determine the effects of changing marketing strategies, knowledge management and transformational leadership. [10], [17], [18], [24], [25], [51] have revealed that learning organizations have a positive and significant influence on company performance.

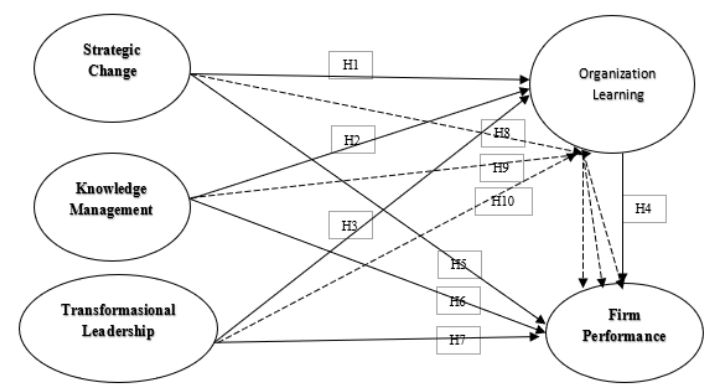

Fig 1 Conceptual Framework

\subsection{Hypothesis Development}

Several studies state that strategic change is a major source of improving company performance [29]. Uncertainty in the future and environmental changes will always occur in a company [52]. When a company faces high uncertainty, the company tends to take advantage of the existing knowledge that has been accumulated from past experiences to make the company stronger [10]. The learning organization is an important part of the change process. The learning capacity in organizations has a major effect on future decision making [50] and is in line with changes in corporate strategy [10]. Learning organizations are an important item in creating customer value in changing company performance more effectively and efficiently [53]. The organizational capacity to learn becomes a competitive advantage for the company. By changing the right strategy and implementing a good learning organization, the company will be able to improve its performance and be able to survive in the future. Learning organizations allow companies to have new breakthroughs in a dynamic changing environment. The strategic change that is the focus of this research is the change in the marketing strategy conceptualized in the research[8], [29] which then began to be developed in research [10]. From some literature that examines the effect of changing strategies and changing marketing strategies on learning organizations, it results in an influence between the two [10]. Based on the above arguments, the hypotheses that can be built are: $\mathrm{H} 1$ : Changes in marketing strategies have an effect positive towards the learning organization. 


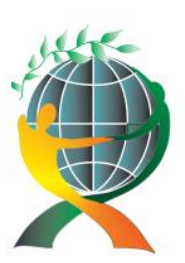

\author{
(online) $=$ ISSN $2285-3642$ \\ ISSN-L = $2285-3642$ \\ Journal of Economic Development, Environment and People \\ Volume 10, Issue 3, 2021 \\ URL: http://jedep.spiruharet.ro \\ e-mail: office jedep@spiruharet.ro
}

Knowledge management is important for company growth. This knowledge is an important element for companies to obtain information that is important as innovation [18]. Some of the literature examines the influence of knowledge management on learning organizations. Knowledge management forms a model that can enhance learning by applying new knowledge [19]. Learning organizations provide complex knowledge and then transform it into new products and services. Learning organizations allow companies to be competitive against new knowledge [18]. Learning organizations are understood as a process in which organizational members are stimulated continuously through new thinking approaches to acquire and share knowledge. This learning organization includes knowledge acquisition, information distribution, collective information storage, interpretation and memorization. Some authors use the terms acquisition, improvement, manufacture and implementation [54]. Based on the previous literature and the results of existing analysis, it can be concluded that to improve learning organizations in an organization at different levels, it is necessary to build a system based on management. Knowledge in some literature knowledge management has an influence on learning organizations [18] and also has an influence on company performance[20]. H2: Knowledge management has a positive effect on the learning organization

Transformational leadership is very important in advancing and developing learning organizations [48]. This allows organizations to learn through experimentation, dialogue and communication. Learning organizations are the company's ability to continuously learn about environmental changes. With good transformational leadership, learning organizations can be carried out effectively [48]. Transformational leadership must be able to encourage learning organizations to have a positive impact on improving company performance [24]. This leadership style analyzes, modifies and drives the system, designing it to share and transfer knowledge through the learning process in order to improve company performance [48], [55]. Transformational leadership is committed to encouraging learning and providing all that is needed to overcome barriers that might hinder the learning process to achieve better company performance. [55]. Based on the above assumptions, a hypothesis can be drawn as follows: H3: Transformational leadership has a positive effect on the learning organization

Learning organizations have a tendency to change the mindset of the company in terms of strategies, systems, methods and provide new alternatives to be able to compete with competitors [10]. Learning organizations have an influence on improving company performance because learning organizations do not only describe what, why, when and how, but how companies react to the symptoms that companies must face in order to have better performance [10]. The company's ability to learn is a competitive advantage in today's intense competition [53]. Learning organizations are the company's main strategy in providing new breakthroughs to improve company performance that allow new opportunities to emerge in competition [53]. Several literatures have examined the influence of learning organizations on company performance, so that the following hypotheses can be drawn: H4. Learning organizations have a positive effect on company performance

Change in strategy is one of the most strategic ways to improve company performance [6], [7]. Changes in strategy are a way for companies to improve their performance better [5]. Several previous studies explained that companies that issue new products always analyze the relationship between decision making and changes in corporate strategy [10]. In some literature strategy change can focus on changes in product strategy, geographic expansion and changes in corporate cognitive reorientation. There have been many positive effects between strategy change and company performance [6], [11], [12]. Based on the theory of organizational behavior, founded by Cyert and March (1963), managers usually compare the target level of performance periodically with the performance of the company. [11]-[14]. For example, 


\author{
(online) $=$ ISSN $2285-3642$ \\ ISSN-L = $2285-3642$ \\ Journal of Economic Development, Environment and People \\ Volume 10, Issue 3, 2021 \\ URL: http://jedep.spiruharet.ro \\ e-mail: office jedep@spiruharet.ro
}

Vicente and Lorente (2006) determined that strategy change had a positive effect on the likelihood of organizational survival in a sample of banks in the Spanish context. Barker and Duhaime (1997) have presented empirical evidence that shows that the level of strategic change carried out is successful and according to the needs and ability of the organization to redirect its strategy. Several studies have found different results. Strategic changes were also found to have a negative impact on organizational performance. For example, Naranjo-Gil et al. (2008) found a negative effect of strategy change on organizational performance. Several other literature examines the effect of strategic change on firm performance resulting in a significant effect between the two [9], [10], [56]. Based on the above arguments, it can be concluded that strategic change will have a significant effect on organizational performance. Based on these reasons, a hypothesis can be built: H5: Changes in marketing strategies have a positive effect on company performance

Several literatures have discussed the effect of knowledge management on improving company performance. Some of the literature that examines the effect of knowledge management on improving company performance [20][18]. Knowledge is an important element for companies to obtain important information as innovation [18] and is a source of sustainable competitive advantage [30]. Knowledge management is used as a management tool to support the achievement of company goals and as a source of competitive advantage to create increased company performance [57]. Knowledge-based resources are an approach to measuring company performance. Knowledge-based resource theory states that knowledge is the most strategic resource and is not easily imitated by other companies (competitors). Based on the literature above, the following hypothesis can be taken: H6. Knowledge management has a positive effect on company performance

Transformational leadership is a process where leaders and subordinates support each other to achieve company goals by achieving better levels of morality and motivation[58]. Transformational leadership provides employees with better motivation [59]. With better motivation, employees will work beyond their limits so that company performance will be better [58]. Transformational leadership behavior that provides support, reinforcement and guidance for employees will foster trust so that it will create closer relationships and have an impact on improving company performance. Some transformational leadership literature affects company performance, because in a dynamic environment, charismatic and visionary leaders play an important role in the success of a company [24]. So that a hypothesis can be drawn that: H7:Transformational leadership has a positive effect on company performance

Some literature that examines the effect of changes in strategy and firm performance predicts that companies with strong learning organizations will have a positive effect on strategic changes on company performance and vice versa, weak learning organizations will have a negative impact on strategy changes on performance company [10].

Organizations that frequently change corporate strategy tend to pose a risk of uncertainty in the company. However, companies that have learning organizations that tend to be strong will find it easier to compete in the dynamics of change that have an impact on better performance improvements [8], [10]. Organizations with strong learning will benefit from a low cost of change, compared to companies with weak learning organizations. This cost advantage is obtained because the duration of the implementation of the change process by the company will be faster so that it can reduce the costs incurred by the company. Companies with low learning organizations create organizational lags allowing for long process of change across business units. In the long run, failure to gain competitive advantage through strategy changes can result in deterioration of the company's performance. Based on this argument, a hypothesis is 


\author{
(online) $=$ ISSN $2285-3642$ \\ ISSN-L = $2285-3642$ \\ Journal of Economic Development, Environment and People \\ Volume 10, Issue 3, 2021 \\ URL: http://jedep.spiruharet.ro \\ e-mail: office jedep@spiruharet.ro
}

drawn as follows: H8: Learning organizations mediate the effect of changing marketing strategies on company performance.

Knowledge management is a model designed with the entry of new knowledge which is then applied in the company [19]. Good knowledge management will affect company performance [17], [19]-[21]. Based on some literature that examines knowledge management and company performance mediated by learning organizations in the public sector in Egyptian [17], it is argued that companies that develop organizational learning processes will improve company performance [17]. A strong learning organization will affect the level of knowledge management which will then affect the company's performance which is getting better [19] and a weak learning organization will affect knowledge management so that the company experiences decreasing performance [17]. Based on the above arguments, conclusions can be drawn to be able to build the following hypothesis: H9: Learning Organizations mediate the influence of knowledge management on company performance

Transformational leadership explains that the potential for employees or subordinates to be directed and developed in achieving organizational goals [44]. With the importance of learning organizations in transformational leadership, it is expected to be part of improving company performance. Leadership that motivates and directs subordinates if supported by experience and knowledge in the past will make changes in performance for the better. Transformational leadership is committed to encouraging learning and providing all that is needed to overcome barriers that may hinder the learning process to achieve better corporate performance [55]. The role of learning organizations cannot be separated from transformational leadership because the existence of a learning organization can form professional, experienced and competent leaders and provide sustainable impacts and benefits for the company [55]. Based on the above discussion, a hypothesis can be concluded. that: H10: Learning organizations mediate the effect of transformational leadership on firm performance.

\title{
3. Research Methodology
}

\subsection{Sampel and Data Collection Process}

The sample in this study uses Islamic banksin Jakarta - Indonesia as a unit of analysis with a purposive sampling technique in which sampling is based on criteria. Based on the results of this research, only select Islamic banking which has branches of more than 100 branches, total assets of 30 trillion rupiah and is in the DKI Jakarta area. Respondents in this study are managers and supervisors / officers in Islamic banks. Based on the determined criteria, there are 4 Islamic banks that meet the requirements. In periode February 2020 to September 2020 where as many as 239 respondents answered the questionnaire and 11 of them did not meet the requirements so that there were 228 respondents who could be used in this study.

\subsection{Variable Measure and Scale Validation}

Marketing strategic change in this study were adopted from strategic change research in this study focused on changes in marketing strategy (MSC) which was adopted from [4]. The items used were adopted from the research [10] as many as 6 question items. The independent variable Knowledge management adopts the questions from [60] research. Knowledge management is measured by 3 indicators, namely knowledge acquisition, knowledge dissemination and knowledge response. The transformational leadership variable in this study adopts statements from [26] and [25] using 5 statement items. The 


\author{
(online) $=$ ISSN $2285-3642$ \\ ISSN-L = $2285-3642$ \\ Journal of Economic Development, Environment and People \\ Volume 10, Issue 3, 2021 \\ URL: http://jedep.spiruharet.ro \\ e-mail: office jedep@spiruharet.ro
}

learning organization variable adopts a statement from [10]which has been modified from previous research [61]. In his research [61] explains the dimensions of learning organizations, namely clarity of vision and mission, commitment and leadership empowerment, experimentation and appreciation, effective knowledge transfer, and teamwork and problem solving.. The learning organization in this study has 7 statement items. The company's performance variable is the dependent variable in this study measured by adopting a statement from [10] which has been modified from several dimensions [62]-[64] with 7 statement items. This study uses a questionnaire with a Likert scale of $1-5$ where $1=$ strongly disagree, $2=$ disagree, $3=$ neutral, $4=$ Agree and $5=$ Strongly Agree [10]

\title{
4. Result and Discussion
}

This study uses data analysis techniques with multivariate analysis. Multivariate analysis is used to test descriptive statistics (mean and standard deviation) and differential statistics to test hypotheses in research. This multivariate analysis will use theanalysis tool Structural Equation Model (SEM). Good research really depends on the measuring instruments used in the research. The Structural Equation Model (SEM) in this study is based on Partial Least Square (PLS). Covariance-based SEM generally tests causality while PLS is more of a predictive model.

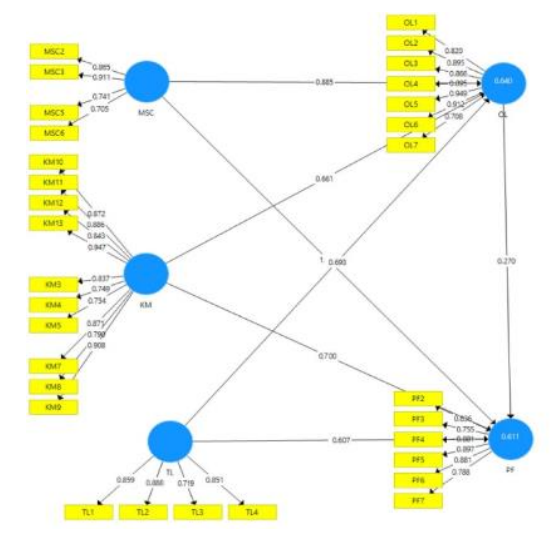

Fig 2 Outer Model Validity and Reliability Testing

This study uses a questionnaire to collect data in the study so that it can be used to explain the intended variables. SmartPls 3.0 is used to determine the level of validity in this study. According to [65] validity is the extent to which the results of the study (1) accurately represent the data collected (internal validity) and (2) can be generalized or transferred to other contexts (external validity). Validity testing aims to determine whether the statement items used in the study can measure the research variables appropriately. Validity testing is done by looking at the content validity and construct validity. Content validity is the extent to which the measurement of the instrument can represent all the characteristics of the variables. Content validity is judgmental.

Convergent validity is a test conducted to determine the effect between variables and indicators. The higher the value loading factor, the higher the correlation and the indicator is declared valid or feasible. Convergent validity is assessed based on the loading factor. To assess the convergent validity, the value loading factor correlates $>0.7$. [65]. Based on the PLS 3.0 results, it can be concluded that the marketing 


\author{
(online) $=$ ISSN $2285-3642$ \\ ISSN-L = $2285-3642$ \\ Journal of Economic Development, Environment and People \\ Volume 10, Issue 3, 2021 \\ URL: http://jedep.spiruharet.ro \\ e-mail: office jedep@spiruharet.ro
}

strategy change has 4 qualifying statements (MSC2, MSC3, MSC5 and MSC6). Knowledge management has 10 valid statements, namely (KM3, KM4, KM5, KM7, KM8, KM9, KM10, KM1, KM12 and KM 13) while transformational leadership has 4 statements that meet the requirements, namely (TL1, TL2, TL3 and TL4). The Learning Organization has 7 items that meet the requirements, namely (OL1, OL2, OL3, OL4, OL5, OL6 and OL7) while the company's performance has 6 items that meet the requirements, namely PF2, PF3, PF4, PF5, PF6 and PF7. Based on the Average Variance Extracted (AVE) value, each value is above the requirement of 0.5 where $\mathrm{MSC}=0.638, \mathrm{KM}=0.719, \mathrm{TL}=0.675, \mathrm{OL}=0.751$ and $\mathrm{PF}=0.608$

Reliability is a measure of a questionnaire / statement item that meets consistent criteria, which means that this statement can have consistent results when used to measure at different places and times. Composite reliability is used to assess whether the indicators on the research variable are reliable or not. An indicator is said to be reliable if the value of composite reliability is high. To assess reliability, the value is composite reliability $>0.7$ [65]. Based on the results of the PLS 3.0 test, it shows that the value of the composite reliability of $\mathrm{MSC}=0.874$, knowledge management $=0.962$, company performance $=0.935$

\title{
4.1. Hypothesis Testing
}

Testing is used to test how the effect of the independent variable and the dependent variable is. To find out whether a research hypothesis is accepted or rejected, it can be seen from its significance level ( $\alpha=$ 0.05 ) in this test it has a confidence level of $95 \%$ and a standard error of $5 \%$ can use a comparison between the values t-table and t-statistic [66].

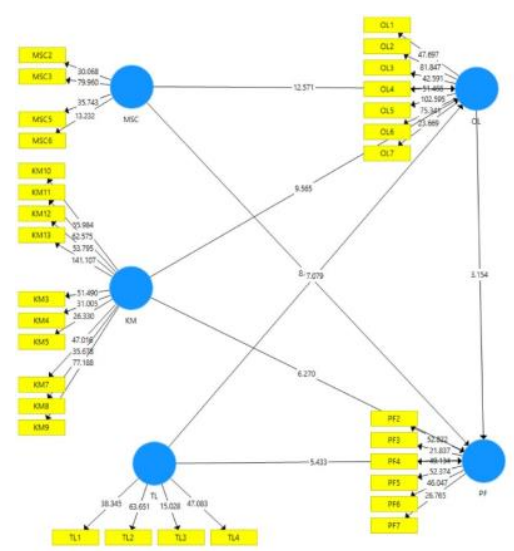

Fig 3 Bootstraping Diagram - Inner Model (Hypothesis Testing)

Hypothesis testing is used to answer the hypotheses proposed in this study. In hypothesis testing is done by means of bootstrapping the described as follows in Tabel 1: 


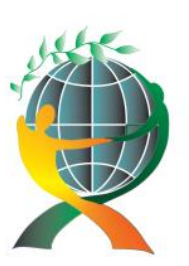

\author{
(online) $=$ ISSN $2285-3642$ \\ ISSN-L = $2285-3642$ \\ Journal of Economic Development, Environment and People \\ Volume 10, Issue 3, 2021
}

URL: http://jedep.spiruharet.ro

e-mail: office jedep@spiruharet.ro

\begin{tabular}{|c|c|c|c|c|c|c|c|}
\hline Hipotesis & Variabel & $\begin{array}{c}\text { Coefficients/ } \\
\text { Original } \\
\text { Sampel (O) }\end{array}$ & $\begin{array}{c}\text { Sample } \\
\text { Mean } \\
(\mathbf{M})\end{array}$ & $\begin{array}{c}\text { Standard } \\
\text { Deviation } \\
(\mathbf{S T D E V})\end{array}$ & $\begin{array}{c}\text { T- } \\
\text { Statistic }\end{array}$ & P-Values & Conclusions \\
\hline $\mathrm{H} 1$ & $\mathrm{MSC} \rightarrow \mathrm{OL}$ & 0,885 & 0,878 & 0,070 & 12,571 & $\mathbf{0 , 0 0 0}$ & Accepted \\
\hline $\mathrm{H} 2$ & $\mathrm{KM} \rightarrow \mathrm{OL}$ & 0,661 & 0,665 & 0,069 & 9,565 & $\mathbf{0 , 0 0 0}$ & Accepted \\
\hline $\mathrm{H} 3$ & $\mathrm{TL} \rightarrow \mathrm{OL}$ & 0,693 & 0,679 & 0,098 & 7,079 & $\mathbf{0 , 0 0 0}$ & Accepted \\
\hline $\mathrm{H} 4$ & $\mathrm{OL} \rightarrow \mathrm{PF}$ & 0,270 & 0,272 & 0,086 & 3,154 & $\mathbf{0 , 0 0 2}$ & Accepted \\
\hline $\mathrm{H} 5$ & $\mathrm{MSC} \rightarrow \mathrm{PF}$ & 1,054 & 1,051 & 0,120 & 8,812 & $\mathbf{0 , 0 0 0}$ & Accepted \\
\hline $\mathrm{H} 6$ & $\mathrm{KM} \rightarrow \mathrm{PF}$ & 0,700 & 0,731 & 0,112 & 6,270 & $\mathbf{0 , 0 0 0}$ & Accepted \\
\hline $\mathrm{H} 7$ & $\mathrm{TL} \rightarrow \mathrm{PF}$ & 0,607 & 0,604 & 0,148 & 5,433 & $\mathbf{0 , 0 0 0}$ & Accepted \\
\hline
\end{tabular}

Tabel 1 - Hypotheses Testing Direct Influence

Based on the Tabe 1 of the hypothesis above, it shows that strategic marketing change affects the learning organization with a confidence level $p$ - value 0.05 then $(0.000<0.05)$ with $t$ - statistic of 12.571 and original sample of 0.085 . These results explain that $\mathrm{H} 1$ is accepted where strategic marketing change affects the learning organization with a positive influence. The more strategic change marketing that is carried out will improve the learning organization. This research is in line with research [10]. Knowledge management has a $p$-value of 0.000 with a confidence level $p$-value 0.05 , then $(0.000<0.05)$ and the tstatistic value of 9.565 is greater than the t-table value of 1.971 (9.565> 1.971) so that it can be concluded that the hypothesis $(\mathrm{H} 2)$ is accepted where knowledge management affects the learning organization. Based on the results of this hypothesis the value of coefficients / original sample is 0.661 which means that the influence of knowledge management has a positive effect on the learning organization. Transformational leadership has a $p$-value of 0.000 with a confidence level $p$-value 0.05 , then $(0.000<0.05)$ and the t-statistic value of 7.079 is greater than the t-table value of $1.971(7.079>1.971)$ so that it can be concluded that the hypothesis $(\mathrm{H} 3)$ is accepted where transformational leadership affects the learning organization. Based on the results of this hypothesis, the value of coefficients / original sample is 0.693 which means that the effect of transformational leadership has a positive effect on the learning organization.

Based on the tabel 1 of hypothesis testing above, the learning organization has a p-value of 0.002 with a confidence level $p$-value 0.05 , then $(0.002<0.05)$ and the t-statistical value of 3.154 is greater than the $t$ table value of 1.971 (3.154> 1.971) so that it can be concluded that the hypothesis $(\mathrm{H} 4)$ is accepted where the learning organization affects company performance. Based on the results of this hypothesis the value of coefficients / original sample is 0.270 , which means that the influence of learning organizations has a positive effect on company performance. Strategic change has a $p$-value of 0.000 with a confidence level $p$ value 0.05 , then $(0.000<0.05)$ and the t-statistic value of 8.812 is greater than the t-table value of 1.971 (8.812> 1.971) so that it can be concluded that the hypothesis (H5) is accepted where changes in marketing strategies affect company performance. Based on the results of this hypothesis, the value of coefficients / original sample is 1.054, which means that the effect of changes in marketing strategy has a positive effect on company performance. Knowledge management has a $p$-value of 0.000 with a confidence level $p$-value 0.05 , then $(0.000<0.05)$ and the t-statistic value of 6.270 is greater than the $t$-table value of $1.971(6.270>$ 1.971) so it can be concluded that the hypothesis (H6) is accepted where knowledge management affects company performance. Based on the results of this hypothesis, the value of coefficients / original sample is 0.700 , which means that the influence of knowledge management has a positive effect on company 


\author{
(online) $=$ ISSN $2285-3642$ \\ ISSN-L = $2285-3642$ \\ Journal of Economic Development, Environment and People \\ Volume 10, Issue 3, 2021 \\ URL: $\underline{\text { http://jedep.spiruharet.ro }}$ \\ e-mail: office jedep@spiruharet.ro
}

performance. Transformational leadership has a p-value of 0.000 with a confidence level $p$-value 0.05 , then $(0.000<0.05)$ and the t-statistic value of 5.433 is greater than the t-table value of $1.971(5.433>1.971)$ so that it can be concluded that the hypothesis $(\mathrm{H} 7)$ is accepted where transformational leadership affects company performance. Based on the results of this hypothesis, the value of coefficients / original sample is 0.607, which means that the effect of transformational leadership has a positive effect on company performance.

The following are the results tabel 2 of hypothesis testing the effect of mediation on this study:

\begin{tabular}{|c|c|c|c|c|c|c|c|}
\hline Hipotesis & Variabel & $\begin{array}{c}\text { Coefficients/ } \\
\text { Original } \\
\text { Sampel (O) }\end{array}$ & $\begin{array}{c}\text { Sample } \\
\text { Mean } \\
(\mathbf{M})\end{array}$ & $\begin{array}{c}\text { Standard } \\
\text { Deviation } \\
\text { (STDEV) }\end{array}$ & $\begin{array}{c}\text { T- } \\
\text { Statistic }\end{array}$ & $\begin{array}{c}\text { P- } \\
\text { Values }\end{array}$ & Conclusions \\
\hline H8 & MSC $\rightarrow$ OL $\rightarrow$ PF & 0,239 & 0,241 & 0,083 & 2,887 & $\mathbf{0 , 0 0 4}$ & Accepted \\
\hline H9 & KM $\rightarrow$ OL $\rightarrow$ PF & 0,178 & 0,179 & 0,061 & 2,919 & $\mathbf{0 , 0 0 4}$ & Accepted \\
\hline H10 & TL $\rightarrow$ OL $\rightarrow$ PF & 0,167 & 0,168 & 0,068 & 2,731 & $\mathbf{0 , 0 0 7}$ & Accepted \\
\hline
\end{tabular}

Tabel 2 Hypothesis Testing Indirect Influence

The Effect of strategic change on firm performance is mediated by a learning organization has a value of $p$ - value of 0.004 with a degree of confidence level $p$-value 0.05 , then $(0.004<0.05)$ and the t-statistic value of 2.887 is greater than the $t$-table value of 1.971 (2.887> 1.971) so it can be concluded that the hypothesis $(\mathrm{H} 8)$ is accepted where changes in marketing strategy affect mediated company performance. by learning organizations. Based on the results of this hypothesis, the value of coefficients / original sample is 0.239 , which means that the effect of changes in marketing strategy has a positive effect on company performance mediated by the learning organization. Knowledge management has a $p$-value of 0.004 with a confidence level $p$-value 0.05 , then $(0.004<0.05)$ and the $t$-statistic value of 2.919 is greater than the $t$-table value of $1.971(2.919>1.971)$ so that it can be concluded that the hypothesis ( $\mathrm{H} 9)$ is accepted where knowledge management affects mediated company performance. by learning organizations. Based on the results of this hypothesis the value of coefficients / original sample is 0.178 , which means that the influence of knowledge management has a positive effect on company performance which is mediated by the learning organization. Transformational leadership has a $p$-value of 0.007 with a confidence level $p$-value 0.05 , then $(0.007<0.05)$ and the $t$-statistical value of 2.731 is greater than the t-table value of $1.971(2.731>$ 1.971) so that it can be concluded that the hypothesis ( $\mathrm{H} 10)$ is accepted where transformational leadership has an effect on mediated company performance. by learning organizations. Based on the results of this hypothesis the value of coefficients / original sample is 0.167 , which means that the effect of transformational leadership has a positive effect on company performance which is mediated by the learning organization.

\title{
4.2. Discussion of Finding
}

Based on the results of hypothesis testing, it can be concluded that the hypothesis ( $\mathrm{H} 1)$ is accepted where changes in marketing strategies affect the learning organization. This research is in line with research [10]. Positive influence can be defined as the more changes in marketing strategies are made to achieve company goals, the better the company's performance. These findings make it clear that strategic change is a major source of improving company performance [29]. Changes in marketing strategies are also the answer to future uncertainty regarding changes in the company's environment [52]. Changes in marketing 


\author{
(online) = ISSN $2285-3642$ \\ ISSN-L = $2285-3642$ \\ Journal of Economic Development, Environment and People \\ Volume 10, Issue 3, 2021 \\ URL: http://jedep.spiruharet.ro \\ e-mail: office jedep@spiruharet.ro
}

strategies made by Islamic banks are changes in marketing strategies for products, for example during the Covid 19 pandemic, Islamic banks made many changes to improve company performance. This change will automatically increase the learning organization of Islamic banks so that in the future Islamic banking will have the ability to adapt quickly because companies have learned and are accustomed to making changes. When a company faces high uncertainty, the company tends to change its strategy to follow the existing market dynamics and has accumulated from past experiences to make the company stronger [10]. The learning organization is an important part of the change process. Learning capacity in organizations has a major influence on future decision making [50] and is in line with changes in corporate strategy [10].

Based on the results of the hypothesis test, it can be concluded that the hypothesis $(\mathrm{H} 2)$ is accepted where knowledge management affects the learning organization. This research is in line with research conducted by [17], [18], [51]. The effect of knowledge management on learning organizations is positive so it can be concluded that the higher the knowledge management, the better the company's learning organization. The results of this study confirm that knowledge management is a previous part of learning organizations or it can be said that knowledge management is the cause of learning organizations [51]. The concept of learning organization can work well because it focuses on getting used to learning through sources of knowledge that can be obtained from knowledge management. This study shows that knowledge management has been implemented properly so that the company is able to direct its employees to always adapt to changes that have an impact on company performance. Knowledge management is able to produce information about the organization's internal and external environment, as well as financial and non-financial information. This information is valuable material in corporate learning [67].

Based on the results of hypothesis testing, it can be concluded that the hypothesis ( $\mathrm{H} 3$ ) is accepted. The positive influence of transformational leadership on learning organizations explains that the better transformational leadership in the organization will increase the learning organization in the company. This research is in line with research conducted by [24], [25]. Transformational leadership is very important in advancing learning organizations. Organizational competition and a complex environment make a company must have dynamic leadership [25]. Learning organizations are the company's ability to continuously learn about environmental changes. With good transformational leadership, learning organizations can be carried out effectively [48]. The results of this study also explain that transformational leadership can influence the creation of a learning organization. Sources of transformational leadership in the form of idealized influence, inspirational motivation, individual attention and intellectual simulations are able to shape employees in the organization to be able to increase their capacity so that they are adaptive to environmental changes and the role of transformational leadership in providing a significant influence in creating learning organizations in order to achieve increased performance and corporate competitive advantage[67].

Based on the results of hypothesis testing, it can be concluded that the hypothesis (H5) is accepted where there is an influence of the learning organization on company performance. The influence of the learning organization on positive performance means that the higher the learning organization in the company, the higher the company's performance and vice versa. This research is in line with research conducted by [10], [17], [24], [51]. The application of learning organizations in companies requires companies to continue to learn to adapt easily to dynamic environmental changes [10]. This finding is increasingly strong in explaining the role of learning organizations in improving company performance. Learning organizations have an influence on improving company performance because learning 


\author{
(online) = ISSN $2285-3642$ \\ ISSN-L = $2285-3642$ \\ Journal of Economic Development, Environment and People \\ Volume 10, Issue 3, 2021 \\ URL: http://jedep.spiruharet.ro \\ e-mail: office jedep@spiruharet.ro
}

organizations do not only describe what, why, when and how, but how companies react to the symptoms that companies must face in order to have better performance [10].

Based on the results of hypothesis testing, it can be concluded that the hypothesis $(\mathrm{H} 4)$ is accepted where changes in marketing strategies have an effect on company performance. The effect of changes in marketing strategies on positive performance further clarifies the role of changes in marketing strategies in improving company performance. This means that the more changes in marketing strategy within the company will increase the company's performance and vice versa. This is in line with research conducted by [6], [10]-[12], [14]. Strategic change is the most strategic way to improve company performance [6], [7]. These findings further strengthen the change in marketing change strategy into a way for companies to improve their performance better ([5]. Companies that make changes always analyze the effect of decision making with changes in corporate strategy that have been made [10]. Different views regarding strategic changes that must be carried out when the company is in a state of decline [6], [11] or in a state of survival and improving performance [36] with a change in strategy is not an important part because of both views.

Based on the results of hypothesis testing, it can be concluded that the hypothesis (H6) is accepted where knowledge management has an effect on company performance. The positive influence of knowledge management on company performance means that the higher the knowledge management in the company, the higher the company's performance and vice versa. This study is in line with research [17], [18], [51] which concluded that knowledge management affects company performance. These results further explain the importance of knowledge in improving organizational performance. Knowledge management is essential for company growth and performance. This knowledge is an important element for companies to obtain important information as innovation [18]and is a source of sustainable competitive advantage [30]. Knowledge management is used as a management tool to support the achievement of company goals and as a source of competitive advantage to create increased company performance [57].

Based on the results of hypothesis testing, it can be concluded that the hypothesis (H7) is accepted where transformational leadership affects company performance. The positive effect of transformational leadership on company performance means that the higher the transformational leadership in the company, the higher the company's performance will increase and vice versa. This research is in line with research conducted by [25] which concluded that transformational leadership has an effect on company performance. Transformational leadership provides employees with better motivation [59]. With better motivation, employees will work beyond their limits so that company performance will be better [58] . Transformational leadership that comes from idealized influences such as charisma will bring out emotions and strong employee identification to their superiors. Leaders who have high charisma will provide certain emotional experiences to their employees, where employees will obey and imitate what their superiors do ( role models). So that the higher the charisma in transformational leadership, the employees will admire their superiors and will work better [58].

Based on the results of hypothesis testing, it can be concluded that the hypothesis $(\mathrm{H} 8)$ is accepted where changes in marketing strategies have an effect on company performance which is mediated by the learning organization. The effect of changes in marketing strategies on performance mediated by positive learning organizations means that the more changes in marketing strategies within the company that are mediated by the learning organizations will increase company performance and vice versa. This research is in line with research conducted by [10]. This finding further strengthens the effect of changes in strategy and company performance mediated by good learning organizations that will have a positive effect, otherwise the mediating role of bad learning organizations will have a negative impact on changes in 


\author{
(online) $=$ ISSN $2285-3642$ \\ ISSN-L = $2285-3642$ \\ Journal of Economic Development, Environment and People \\ Volume 10, Issue 3, 2021 \\ URL: http://jedep.spiruharet.ro \\ e-mail: office jedep@spiruharet.ro
}

marketing strategies on company performance [10] An increasingly strong, dynamic and changing organizational environment and competition creates a risk of uncertainty in the company. However, companies that have learning organizations that tend to be strong will find it easier to compete in the dynamics of change that have an impact on better performance improvements [8], [10]. Organizations with strong learning will benefit from a low cost of change, compared to companies with weak learning organizations. This cost advantage is obtained because the duration of the implementation of the change process by the company will be faster so that it can reduce the costs incurred by the company. Companies with low learning organizations create organizational lags allowing for long process of change across business units. In the long run, failure to gain a competitive advantage through strategy changes can result in a decline in company performance [10]. However, the mediating role of the learning organizations in this study is less than optimal compared to the direct influence this can be caused by changes that occur very quickly compared to the learning process itself. Barriers to learning organizations also become an important part of learning organizations that are not optimal, such as support from top management, low corporate learning culture and little learning time.

Based on the results of hypothesis testing, it can be concluded that the hypothesis (H9) is accepted where knowledge management affects company performance mediated by the learning organization. The effect of knowledge management on performance mediated by the learning organization which is positive means that the higher the knowledge management in the company that is mediated by the learning organization, the higher the company's performance and vice versa. This research is in line with research conducted by [51]. The role of knowledge management and learning organizations is considered as an important factor in improving company performance. In practice, the role of the learning organization is inseparable and inseparable in bridging the influence between knowledge management and company performance [18]. In this unit of analysis, the role of the learning organization has an indirect effect that is lower than the direct effect of knowledge management on company performance. The capacity of a learning organization is a knowledge system infrastructure in an organization, while knowledge management is related to strategy [51]. In this study, the mediating role of the learning organizations has the greatest influence on the influence of knowledge management on company performance. This is because the learning organization is supported by good knowledge management so that the quality and quantity of knowledge acquired and disseminated becomes strengthening for learning organizations and indirectly improves the performance of Islamic banks.

These findings also further clarify the effect of knowledge management on company performance [17], [19]-[21]. Knowledge management is a model designed with the entry of new knowledge which is then applied in companies [19]. These findings also make it clear that organization learning processes will improve company performance [17]. A strong learning organization will affect the level of knowledge management which will then affect the company's performance which is getting better [19] and a weak learning organization will affect knowledge management so that the company experiences decreasing performance [17]. Companies that have a strong learning organization will find it easier to make decisions in the future because the knowledge that has been built and managed properly can make important information in decision making and determining future strategies.

The mediation role of learning organizations makes the management of knowledge owned by the company easier to implement and use to improve company performance in the future, because organizations are accustomed and are constantly learning to be able to use their knowledge to be able to 


\author{
(online) $=$ ISSN $2285-3642$ \\ ISSN-L = $2285-3642$ \\ Journal of Economic Development, Environment and People \\ Volume 10, Issue 3, 2021 \\ URL: http://jedep.spiruharet.ro \\ e-mail: office jedep@spiruharet.ro
}

adapt to changes in the future. However, in this study the role of mediation is still less than optimal when compared to the direct effect of knowledge management on company performance. This can occur because the quality of information and knowledge acquisition is not good and there are obstacles that prevent the learning organization from running optimally.

Based on the results of hypothesis testing, it can be concluded that the hypothesis ( $\mathrm{H} 10)$ is accepted where transformational leadership has an effect on company performance which is mediated by the learning organization. The effect of transformational leadership on performance mediated by positive learning organizations means that the higher the transformational leadership in a company that is mediated by the learning organization, the higher the company's performance and vice versa. This research is in line with research [55], but not in line with the research conducted [24]. This study shows a positive influence between transformational leadership and company performance mediated by learning organizations. This leadership style analyzes, modifies and drives the system, designing it to share and transfer knowledge through the learning process to improve company performance [55]. These findings further clarify transformational leadership that is committed to fostering learning and providing all that is needed to overcome barriers that may hinder the learning process to achieve better company performance [55]. Transformational leadership explains that the potential for employees or subordinates to be directed and developed in achieving organizational goals [44]. With the importance of learning organizations in transformational leadership, it is expected to be part of improving company performance. Leadership that motivates and directs subordinates if supported by experience and knowledge in the past will make changes in performance for the better. However, in this study, the mediating role of the learning organizations is not optimal. This can be caused by each individual in the leader having different characteristics and abilities so that the implementation of the learning organization has differences. Learning organization with a low system can also be a barrier to learning itself.

\title{
5. Conclusion
}

Based on the results of this study, it can be concluded that strategic change marketing, knowledge management and transformational influence on learning organizations in addition to strategic change marketing, knowledge management and transformational and learning organizations affect company performance. The mediating role of learning organizations also provides positive results in mediating the effects of strategic change, knowledge management and transformational.

\section{Future Research}

The next research can provide recommendations for other factors that affect the performance of Islamic banks. Several previous studies have recommended the role of innovation mediation in improving company performance. The role of innovation is an important part in responding to a dynamic changing environment and intense competition. Many similar studies have been carried out, but this role is considered important in the era of digitalization. Another factor that may become further research can also add to the factor of government support, where government support is an important part of improving the performance of Islamic banks both internally and externally. The government support variable has been the topic of discussion for many researchers and still produces differences and inconsistencies.

\section{References}




\author{
(online) = ISSN $2285-3642$ \\ ISSN-L = $2285-3642$ \\ Journal of Economic Development, Environment and People \\ Volume 10, Issue 3, 2021 \\ URL: http://jedep.spiruharet.ro \\ e-mail: office jedep@spiruharet.ro
}

[1] Y. Wu, Z. Wei, and Q. Liang, "Top management team diversity and strategic change: The moderating effects of pay imparity and organization slack," J. Organ. Chang. Manag., vol. 24, no. 3, pp. 267-281, 2011, doi: $10.1108 / 09534811111132686$.

[2] Kementrian Komunikasi dan Informatika, "SIARAN PERS NO. 53/HM/KOMINFO/02/2018," Siar. PERS NO. 53/HM/KOMINFO/02/2018, p. 1, 2018.

[3] otoritas jasa keuangan, "Statistik Perbankan Syariah - Desember," J. Chem. Inf. Model., vol. 53, no. 9, pp. 1689-1699, 2019.

[4] A. Thoumrungroje, "THE MODERATING ROLES OF ORGANIZATIONAL LEARNING AND STRATEGIC FLEXIBILITY ON MARKETING STRATEGIC CHANGE AND BUSINESS PERFORMANCE: EVIDENCE FROM FIRMS IN THAILAND," Int. Mark. Fast Chang. World Adv. Int. Mark., vol. 26, pp. 179-198, 2015.

[5] N. Pangarkar, "Performance implications of strategic changes: An integrative framework," Bus. Horiz., 2015, doi: 10.1016/j.bushor.2015.01.003.

[6] R. Clarke and B. Buchanan, "Turnaround strategies.," Trustee, vol. 63, no. 6, pp. 19-31, 2010, doi: 10.4324/9781315738116-8.

[7] M. S. Kraatz and E. J. Zajac, "How Organizational Resources Affect Strategic Change and Performance in Turbulent Environments: Theory and Evidence," Organ. Sci., vol. 12, no. 5, pp. 632657, 2001, doi: 10.1287/orsc.12.5.632.10088.

[8] Chaiporn Vithessonthi and Amonrat Thoumrungroje, "Strategic change and firm performance : the moderating effect of organisational learning," 2011, doi: 10.1108/15587891111152348.

[9] M. W. Okonda, D. P. B. Ojera, and D. I. O. Ochieng, "The Moderating Effect of Firm Characteristics on the Relationship between Strategic Change and Performance of Firms in the Alcohol Industry in Kenya," iJARS Int. J. Manag. Corp. Aff., vol. 2, no. 3, 2015, doi: 10.20908/ijarsijmca.v2i3.10784.

[10] H. I. Mohammad, "Mediating effect of organizational learning and moderating role of environmental dynamism on the relationship between strategic change and firm performance," J. Strateg. Manag., vol. 12, no. 2, pp. 275-297, 2019, doi: 10.1108/JSMA-07-2018-0064.

[11] V. L. Barker and I. M. Duhaime, "Strategic change in the turnaround process: Theory and empirical evidence," Strateg. Manag. J., vol. 18, no. 1, pp. 13-38, 1997, doi: 10.1002/(sici)10970266(199701)18:1<13::aid-smj843>3.3.co;2-o.

[12] D. D. Bergh and E. N. Lim, "LEARNING HOW TO RESTRUCTURE: ABSORPTIVE CAPACITY AND IMPROVISATIONAL VIEWS OF RESTRUCTURING ACTIONS AND PERFORMANCE," vol. 616, no. December 2007, pp. 593-616, 2008, doi: 10.1002/smj.

[13] J. Á. Zúñiga-Vicente and J. D. Vicente-Lorente, "Strategic moves and organizational survival in turbulent environments: The case of Spanish banks (1983-97)," J. Manag. Stud., vol. 43, no. 3, pp. 485-519, 2006, doi: 10.1111/j.1467-6486.2006.00599.x. 


\author{
(online) $=$ ISSN $2285-3642$ \\ ISSN-L = $2285-3642$ \\ Journal of Economic Development, Environment and People \\ Volume 10, Issue 3, 2021 \\ URL: http://jedep.spiruharet.ro \\ e-mail: office jedep@spiruharet.ro
}

[14] D. Naranjo-Gil, F. Hartmann, and V. S. Maas, "Top management team heterogeneity, strategic change and operational performance," Br. J. Manag., vol. 19, no. 3, pp. 222-234, 2008, doi: 10.1111/j.1467-8551.2007.00545.x.

[15] R. Farooq, "Developing a conceptual framework of knowledge management," Int. J. Innov. Sci., vol. 11, no. 1, pp. 139-160, 2019, doi: 10.1108/IJIS-07-2018-0068.

[16] H. F. Lin, "Linking knowledge management orientation to balanced scorecard outcomes," J. Knowl. Manag., vol. 19, no. 6, pp. 1224-1249, 2015, doi: 10.1108/JKM-04-2015-0132.

[17] W. Nafei, "The Mediating Effects of Organizational Learning on the Relationship between Knowledge Management and Organizational Performance: An Applied Study on the Egyptian Commercial Banks," Int. J. Bus. Manag., vol. 9, no. 2, pp. 244-261, 2014, doi: 10.5539/ijbm.v9n2p244.

[18] S. R. Khalil and K. K. Mehmood, "Knowledge Management, Emotional Capability, Teamwork, and Innovativeness: Mediating Role of Organizational Learning," Rev. Econ. Dev. Stud., vol. 4, no. 2, pp. 227-235, 2018, doi: 10.26710/reads.v4i2.407.

[19] A. Gunsel, E. Siachou, and A. Z. Acar, "Knowledge management and learning capability to enhance organizational innovativeness," Procedia - Soc. Behav. Sci., vol. 24, pp. 880-888, 2011, doi: 10.1016/j.sbspro.2011.09.012.

[20] M. A. Valmohammadi, Changiz, The impact of knowledge management practices on organizational performance A balanced scorecard approach. 2015.

[21] M. Q. A. Al-qarioti, "EURASIAN JOURNAL OF BUSINESS AND," vol. 3, no. 4, pp. 36-54, 2015, doi: 10.15604/ejbm.2015.03.04.004.

[22] T. Buyukbese, "Knowledge Sharing Process, Innovation Capability and Innovation Performance : An Empirical Study Knowledge Sharing Process, Innovation Capability and Innovation Performance : An Empirical Study," no. November, 2015, doi: 10.1016/j.sbspro.2013.04.025.

[23] R. Rofiaty, T. Noviyanti, and A. D. Mulyanto, "PENGARUH KNOWLEDGE MANAGEMENT TERHADAP KINERJA ORGANISASI: DIMEDIASI OLEH INOVASI, DAN IMPLEMENTASI STRATEGI (Studi pada RS Lavalette Malang)," Iqtishoduna, vol. 1, no. 1, p. 11, 2016, doi: 10.18860/iq.v1i1.3697.

[24] L. Octavia and Devie, "Pengaruh Transformational Leadership Terhadap University Performance Dengan Learning Organization Dan University Culture Sebagai Variabel Intervening," Bus. Account. Rev., vol. 3, no. 1, pp. 489-500, 2015.

[25] A. I. Choudhary, S. A. Akhtar, and A. Zaheer, "Impact of Transformational and Servant Leadership on Organizational Performance: A Comparative Analysis," J. Bus. Ethics, vol. 116, no. 2, pp. 433-440, 2013, doi: 10.1007/s10551-012-1470-8.

[26] V. J. García-Morales, F. J. Lloréns-Montes, and A. J. Verdú-Jover, "The effects of transformational leadership on organizational performance through knowledge and innovation," Br. J. Manag., vol. 


\author{
(online) $=$ ISSN $2285-3642$ \\ ISSN-L = $2285-3642$ \\ Journal of Economic Development, Environment and People \\ Volume 10, Issue 3, 2021 \\ URL: $\underline{\text { http://jedep.spiruharet.ro }}$ \\ e-mail: office jedep@spiruharet.ro
}

19, no. 4, pp. 299-319, 2008, doi: 10.1111/j.1467-8551.2007.00547.x.

[27] C. Valmohammadi and M. Ahmadi, "The impact of knowledge management practices on organizational performance: A balanced scorecard approach," J. Enterp. Inf. Manag., vol. 28, no. 1, pp. 131-159, 2015, doi: 10.1108/JEIM-09-2013-0066.

[28] R. A. P. Perdana, Darminto, and N. Sudjana, "Pengaruh Return On Equity (ROE), Earning Per Share (EPS), Dan Debt Equity Ratio (DER) Terhadap Harga Saham," J. Adm. Bisnis, vol. 2, no. 1, pp. 128137, 2013.

[29] B. B. S. Barbara Stöttinger Shaoming Zou, "International Marketing in the Fast Changing World," Int. Mark. fast Chang. world Adv. Int. Mark., p. https://doi.org/10.1108/02652320010315316 Download, 2015, doi: doi:10.1108/S1474-797920150000026015.

[30] jay barney, "barney1991.pdf." 1991.

[31] J. B. Barney, "Strategic Factor Markets : Expectations , Luck , and Business Strategy," no. September 2015, 1986.

[32] Birger Wernerfelt, "The resource based view of the firm," J. Manag. Inq., vol. 21, no. 1, p. 124, 1984, doi: $10.1177 / 1056492611436225$.

[33] S. Carnahan, R. Agarwal, and B. Campbell, "The Effect of Firm Compensation Structures on the Mobility and Entrepreneurship of Extreme Performers," Business, vol. 146, no. September 2005, pp. 1-43, 2010, doi: 10.1002/smj.

[34] D. Chandler and N. Hynek, "Critical perspectives on human security: Rethinking emancipation and power in international relations," Crit. Perspect. Hum. Secur. Rethink. Emancip. Power Int. Relations, vol. 14, no. 3, pp. 1-208, 2010, doi: 10.4324/9780203847589.

[35] K. Conner, "hostorical comparison of RBV," Journal of Management, vol. 17, no. 1. p. 34, 1991.

[36] H. E. Salavou, "Competitive strategies and their shift to the future," Eur. Bus. Rev., vol. 27, no. 1, pp. 80-99, 2015, doi: 10.1108/EBR-04-2013-0073.

[37] M. Nuhung and I. Pendahuluan, "PERSPEKTIF AL- QUR' AN," pp. 22-29, 2016.

[38] A. H. Van De and M. S. Poole, "Explaining Development and Change in Organizations.," Acad. Manag. Rev., vol. 20, no. 3, pp. 510-540, 1995, doi: 10.5465/amr.1995.9508080329.

[39] T. Dotzel, V. Shankar, and L. L. Berry, "Service innovativeness and firm value," J. Mark. Res., vol. 50, no. 2, pp. 259-276, 2013, doi: 10.1509/jmr.10.0426.

[40] R. M. Grant, "The resource-based theory of competitive advantage: Implications for strategy formulation," Knowl. Strateg., no. December 1999, pp. 3-24, 1996, doi: 10.1016/b978-0-7506-70883.50004-8. 


\author{
(online) $=$ ISSN $2285-3642$ \\ ISSN-L = $2285-3642$ \\ Journal of Economic Development, Environment and People \\ Volume 10, Issue 3, 2021 \\ URL: $\underline{\text { http://jedep.spiruharet.ro }}$ \\ e-mail: office jedep@spiruharet.ro
}

[41] et al Teece, David J, "DYNAMIC CAPABILITIES AND STRATEGIC MANAGEMENT," vol. 18, no. March, pp. 509-533, 1997.

[42] M. D. Cohen and P. Bacdayan, "Organizational Routines Are Stored as Procedural Memory: Evidence from a Laboratory Study," Organ. Sci., vol. 5, no. 4, pp. 554-568, 1994, doi: 10.1287/orsc.5.4.554.

[43] D. A. Schon and V. DeSanctis, "The Reflective Practitioner: How Professionals Think in Action," J. Contin. High. Educ., vol. 34, no. 3, pp. 29-30, 1986, doi: 10.1080/07377366.1986.10401080.

[44] D. Thalib, D. Fitriana, E. Anou, M. Maisyaroh, and R. B. Sumarsono, "Atribusi Bawahan terhadap Pemimpin Berkarisma," Tarbawi J. Keilmuan Manaj. Pendidik., vol. 5, no. 02, p. 205, 2019, doi: 10.32678/tarbawi.v5i02.2088.

[45] Burns, "Leadership," pp. 69-77, 1978, doi: 10.1002/0470007826.ch4.

[46] B. M. Bass and A. P. S. Cruz, "Bass leadership 1985," J. Chem. Inf. Model., vol. 53, no. 9, pp. 16891699, 1985.

[47] Maulizar, S. Musnadi, and M. Yunus, "Pengaruh Kepemimpinan Transaksional Dan Transformasional Terhadap Kinerja Karyawan Bank Syariah Mandiri Cabang Banda," J. Manaj. Pascasarj. Univ. Syiah Kuala, vol. 1, no. 1, pp. 58-65, 2012.

[48] Senge, The Fifth Discipline. 1991.

[49] I. Nonaka, "The Knowledge-Creating Company," no. August, 1991.

[50] S. Keen, Growth theory. 2012.

[51] B. I. Pradana, "Peran Organizational Learning dalam Penerapan Knowledge Management untuk mencapai Organizational Effectiveness," J. Ekon. dan Bisnis Univ. Brawijaya, no. October, pp. 0-10, 2014.

[52] A. Mukherji and J. Mukherji, "Environmental Uncertainty and Positive Performance of Small Firms: The Roles of Key Mediators," Acad. Manag. Proc., vol. 2016, no. 1, p. 10437, 2016, doi: 10.5465/ambpp.2016.10437abstract.

[53] M. L. Santos-Vijande, J. Á. López-Sánchez, and C. González-Mieres, Organizational learning, innovation, and performance in KIBS, vol. 18, no. 6. 2012.

[54] C. L. Wang and P. K. Ahmed, "Organisational learning: A critical review," Learn. Organ., vol. 10, no. 1, pp. 8-17, 2003, doi: 10.1108/09696470310457469.

[55] V. J. García-Morales, M. M. Jiménez-Barrionuevo, and L. Gutiérrez-Gutiérrez, "Transformational leadership influence on organizational performance through organizational learning and innovation," J. Bus. Res., vol. 65, no. 7, pp. 1040-1050, 2012, doi: 10.1016/j.jbusres.2011.03.005.

[56] C. Vithessonthi and A. Thoumrungroje, "Strategic change and firm performance: the moderating 


\author{
(online) = ISSN $2285-3642$ \\ ISSN-L = $2285-3642$ \\ Journal of Economic Development, Environment and People \\ Volume 10, Issue 3, 2021 \\ URL: http://jedep.spiruharet.ro \\ e-mail: office jedep@spiruharet.ro
}

effect of organisational learning," J. Asia Bus. Stud., vol. 5, no. 2, pp. 194-210, 2011, doi: $10.1108 / 15587891111152348$.

[57] N. Puryantini and R. Arfati, "Pengaruh Knowledge Management Terhadap Kinerja Organisasi Dimediasi Inovasi di Organisasi Penelitian Pemerintah," vol. 02, no. 02, pp. 21-38, 2017.

[58] W. Prajogo, "Pengaruh Dimensi-Dimensi Kepemimpinan Transformasional Dan Transaksional Pada Kinerja Karyawan," Modul, vol. 25, no. 2, pp. 125-138, 2013.

[59] B. M. Bass, B. J. Avolio, and D. I. Jung, "Predicting Unit Performance by Assessing Transformational and Transactional Leadership," vol. 88, no. 2, pp. 207-218, 2003, doi: 10.1037/0021-9010.88.2.207.

[60] J. Darroch and J. Darroch, "Knowledge management, innovation and firm performance," no. June 2005, 2015, doi: 10.1108/13673270510602809.

[61] J. M. Sinkula, W. E. Baker, and T. Noordewier, "A framework for market-based organizational learning: Linking values, knowledge, and behavior," J. Acad. Mark. Sci., vol. 25, no. 4, pp. 305-318, 1997, doi: 10.1177/0092070397254003.

[62] G. G. Dess, "Measuring Organizational Performance in the Absence of Objective Measures: The Case of the Privately-held Firm and Conglomerate Business Unit," vol. 5, no. January 1983, pp. 265273, 1984.

[63] J. R. Falshaw and K. W. Glaister, "Evidence on formal strategic planning and company performance," vol. 44, no. 1, pp. 9-30, 2006, doi: 10.1108/00251740610641436.

[64] J. A. Pearce et al., "The Impact of Grand Strategy and Planning Formality on Financial Performance Published by: Wiley Stable URL : http://www.jstor.org/stable/2485977 PLANNING FORMALITY ON FINANCIAL," vol. 8, no. 2, pp. 125-134, 2016.

[65] P. D. H. I. Ghozali and H. Latan, Partial Least Squares Konsep, Teknik dan Aplikasi menggunakan Program SmartPLS 3.0, 2nd ed. Semarang: Badan Penerbit-Undip, 2015.

[66] V. W. Sujarweni, Metodologi Penelitian Bisnis dan Ekonomi Pendektan Kuantitatif. Yogyakarta: PUSTAKABARUPRESS, 2018.

[67] D. Devie, Y. Mangoting, and M. Soengkono, "Pengaruh Leadership Style Terhadap Learning Organization," EKUITAS (Jurnal Ekon. dan Keuangan), vol. 2, no. 3, p. 427, 2019, doi: 10.24034/j25485024.y2018.v2.i3.3962. 